\title{
Pengaruh Hedonic Shopping Value, Web Informativeness, Web Entertainment Terhadap E-Loyalty Dengan E-Satisfaction Sebagai Mediasi Pada Tokopedia
}

\author{
Ellyta Liska Andriani ${ }^{(1)}$ \\ Program Studi Manajemen \\ Universitas Sarjanawiyata Tamansiswa ${ }^{(1)}$ \\ E-mail: ${ }^{1}$ ellytaliska@gmail.com
Ida Bagus Nyoman Udayana ${ }^{(2)}$
Program Studi Manajemen
Universitas Sarjanawiyata Tamansiswa ${ }^{(2)}$ \\ Nonik Kusuma Ningrum ${ }^{(3)}$ \\ Program Studi Manajemen \\ Universitas Sarjanawiyata Tamansiswa ${ }^{(3)}$
}

\begin{abstract}
This research was conducted with in order to identify and analyze the factors that influence loyalty Tokopedia users of online shopping services. With several related variables in this research are hedonic shopping value, web informativeness, web entertainmnet, e-satisfaction, and e-loyalty as dependent variables. The population of this research is tokopedia users, with a sample of 100 tokopedia users. Data collection was done by using a questionnaire method. The test result in this study are that hedonic shopping value has positive effect on e-satisfation, wen informativeness and web entertainmnet have a positive effect on e-satisfaction, and E-Satisfaction has positive effect on $E$ Loyalty. Which Means that hypothesis testing is accepted.
\end{abstract}

Keywords: Hedonic Shopping Value, Web Informativeness, Web Entertainmnet, E-Satisfaction, ELoyalty

\section{PENDAHULUAN}

Perkembangan teknologi nformasi membantu para pelaku usaha mengembangkan usaha mereka, terutama dalam mendatangkan pelanggan serta memberikan umpan balik terhadap produk dan layanan yang ditawarkan. Pembeli juga diuntungkan sebab mereka dapat membandingkan harga, fitur, manfaat dan layanan yang ditawarkan. (Vijay, Prashar, \& Sahay, 2019)

Teknologi informasi dalam proses bisnis biasa disebut e-commerce (McLeod, 2008). Menurut databox (2019) Indonesia perkembangan e-commerce cukup tinggi hingga pada tahun 2009 masuk dalam 10 negara dengan pertumbuhan e-commerce tercepat. Salah satu perusahaan e-commerce di Indonesia adalah Tokopedia. Tokopedia merupakan perusahaan teknologi asal Indonesia yang mempunyai misi mencapai pemerataan ekonomi secara digital yang didirikan tahun 2009. Sejak peluncurannya tokopedia telah melakukan berbagai dongkrakan baru hingga mengelami banyak perkembangan. Dan hingga sekarang aplikasinya sudah didownload oleh lebih dari 50 juta pengguna. (Tokopedia, 2020) 
Permasalahan yang sering dihadapi e-commerce adalah perihal loyalitas pengguna. Pada survey dari Mery weintein (2013) menyatakan 80 persen pengguna melakukan pembelian, sedangkan 50 persen melakukan pembelian berulang. pada penjelasan tersebut memberikan indikasi bahwa loyalitas masih rendah. Dalam bisnis, loyalitas adalah salah satu strategi untuk mempertahankan hubungan baik dnegan para konsumen. Loyalitas dapat dibentuk dengan memberikan kepuasan kepada konsumen.

Menurut Hasan (2008) loyalitas didefinisikan sebagai pembelian yang berulang. Sedangkan Hur et al., (2011) mendefinisikan e-loyalty adalah niatan untuk mengunjungi website berulang dengan atau tidak melakukan transaksi. Menurut (Anderson \& Srinivasan, 2003) mempunyai pengguna yang loyal membantu perusahaan dalam pertumbuhan penjualan jangka panjang. sejalan dengan itu, perusahaan mempunyai peluang mendapat laba dari pertumbuhan penjualan yang baik. Kepuasan yang didapat cenderung akan membuat konsumen kembali meggunakan perusahaan tersebut. (Verhoef dalam Martinez dan Bosque, 2013). Kepuasan terjadi saat sebelum maupun setelah menggunakan suatu produk (Ariningsih 2014). Kepuasan berbenja online dapat terbentuk dari hedonic shopping value, web informativeness, dan web entertainmnet. Membuat pengguna puas adalah tujuan perusahaan agar tercipta loyalitas, yang dapat dilakukan dengan mengetahui kebutuhan konsumen. (Vijay et al., 2019)

Dijelaskan oleh Setiadi (2003) bahwa kebutuhan konsumen pada proses motivasi diekspresikan dengan dua manfaat perilaku pembelian, yaitu utilitarian dan hedonik. Secara spesifik, manfaat hedonik merupakan respon emosional, pertimbangan estetis, dan kesenangan. Manfaat hedonis dapat dilihat saat konsumen berbelanja. Berbelanja meningkatkan stimulasi dan asosiasi, memberikan pilihan, melarikan diri, memberikan fantasi dan aspek emosional lain dari pengalaman pembelian (Vijay et al., 2019). Kegiatan berbelanjan yang dilakukan oleh konsumen hendaknya menikmati prosesnya, disamping itu belanja dapat membagikan keuntungan bagi pelanggan dalam mengikuti tren barang terbaru guna memenuhi kepuasan.

Penelitian yang dilakukan oleh Prashar et al., (2017) menyatakan bahwa desain web yang terdiri dari web informativeness dan web entertainmnet penting dalam memberikan rangsangan bagi konsumen, terlebih dalam membuat konsumen terpuaskan dan menimbulkan niatan untuk datang kembali pada situs web. Web Informativeness merupakan ragam informasi pada web, yang membantu konsumen mengatasi masalah mulai dari info perusahaan, layanan, transaksi, produk, sampai dengan pengiriman, sedangkan Web merupakan unsur-unsuur visual web seperti, tampilan dan tata letak, warna, dan link. Kualitas web dan desain yang berkualitas baik akan mendapatkan kepercayaan dari konsumen dan rasa menyenangkan saat berjelajah di web tersebut. Konsumen akan lebih menekankan pada properti yang disajikan serta sistem kemudahan penggunaan situs web (Ebrahim Mazaheri, Richard, \& Laroche, 2011).

Berdasarkan permasalahan yang muncul seperti yang telah diuraikan, maka rumusan masalah dalam penelitian ini ada1lah:

a) apakah Hedonic Shopping Value berpengaruh positif terhadap E-Satisfaction pada pengguna tokopedia?.

b) apakah Web Informativeness berpengaruh positif terhadap e-satisfaction pada pengguna tokopedia?.

c) apakah web entertainment berpengaruh positif terhadap e-satisfaction?.

d) apakah e-satisfaction berpengaruh positif terhadap e-loyalty?. 


\section{KAJIAN PUSTAKA \\ E-commerce}

E-commerce adalah kegiatan transaksi bisnis secara online melalui media internet (Laudon, 2012). E-commerce merupakan perkembangan tren di lingkungan masyarakat sebagi salah satu upaya untuk memenuhi kebutuhan manusia dengan cara yang lebih efektif dan efisien. Sehingga dapat dikatakan e-commerce atau marketplace merupakan perantara antara pengguna dan pemilik produk. Adanya e-commerce dirasa semakin memudahkan perusahaan dalam menekan biaya pengiriman, menambah konsumen, serta komunikasi dengan konsumen. ( Udayana, \& Pramana, 2019)

\section{Hedonic Shopping Value}

Menurut Irani \& Hanzaee (2013) hedonic shopping value adalah persepsi dimanaberbelanja dianggap sebagai hay yang dipegaruhi dari emosional dan manfaat apa saat konsdisi emosi sedang dalam keadaan positif. Apabila konsumen tersebut memiliki kecenderungan hedonic, maka konsumen tersebut dinilai potensial, karena hedonic dianggap sebagai kegiatan untuk mencari kesenangan dan menghindari masalah dnegan masuk di dalam dunia fantasi dari belanja (Arnold \& Reynolds, 2012)

Batra \& Ahtola (1991) mendefinisikan bahwa keseluruhan evaluasi dari seorang konsumen yang dilandasi pada pmenuhan kesenangannya dapat diartikan sebagai hedonic value. Hedonic merupakan stimulasi yang akan menseleksi dari kualitas lingkungan belanja dari sisi kesenangan atau kenikmatan yang dirasakan, rasa ketertarikan akibat visual dan rasa lega(Sugiyono, 2011).

\section{Web informativeness}

Web Informativeness merupakan jumlah dan kekayaan informasi yang terkandung di dalam sebuah website, termasuk informasi menganai perusahaan, produk, dan layanan, nonkemersial informasi, dan rincian transaksi seperti pembayaran dan pengiriman. Hoffam dan Nofak (1996) berpendapat web informativeness dapat diinterpretasikan sebagai kemampuan dari iklan dalam menyampaikan informasi kepada kosumen dalam rangka mencukupi kebutuhan mereka.

Informativeness merupakan kemampuan untuk menginformasikan kepada pelanggan bahwa produk mereka mampu memberikan kepuasan kepada pelanggan (Gao dan Koufaris, 2006). Siau dan Shen (2003), mengungkapkan bahwa kualitas informasi yang diletakan dalam iklan, dapat mempengaruhi persepsi konsumen terhadap produk yang ditawarkan.

\section{Web Entertainment}

Web entertainment adalah suatu web yang berisi situs yang memberikan informasi mengenai toko melalui iklan web untuk memberikan informasi kepada para usernya secara digital dengan menawarkan informasi yang telah diperbarui. Shimp (1981) juga mengemukakan bahwa entertainment dalam sebuah iklan dapat membuat pelanggan memberikan rasa positif terhadap brand yang diiklankan. Iklan yang menawarkan nilai entertainment yang tinggi kepada pelanggan dapat mendorong pelanggan untuk lebih sering menggunakan media iklan tersebut (Dehghani, Khorram, Ramezani, \& Sali, 2016).

Konsumen mengaharapkan konten dari sebuah media iklan menawarkan pengalaman yang menghibur melalui media yang ada. (Gangadharbatla, Harsha, \& Daugherty, 2013). 


\section{E-satisfaction}

Andrson dan Srinivasan telah mendefinisikan tentang e-satisfaction merupakan kepuasan pelanggan terhadap pengalaman pembelian sebelumnya dengan perusahaan perdagangan elektronik yang diberikan. Kepuasan didefinisikan sebagai keadaan psikologis yang dihasilkan ketika emosi disekitar harapan yang tidak dikonfirmasi dioadukan dengan perasaan konsumen sebelumya tentang pengalaman pelanggan (Valvi \& Konstantinos, 2012).

Menurut Kotler \& Armstrong (2012) nilai pelanggan adalah sebuah perbandingan pelanggan antara semua keuntungan dan sebuah biaya yang harus dikeluarkan untuk menerima penawaran yang diberikan. Keputusan pelanggan sangat bergantung pada persepsi dan ekspetasi pelanggan, oleh karena itu suatu perusahaan perlu mengetahui faktor yang mempengaruhinya.

\section{E-Loyalty}

Cyr (2008) dalam (Christian \& Nuari, 2014) mendefinisikan e-loyalty sebagai niat dari konsumen untuk mengunjungi atau menggunakan suatu website, melakukan pembelian atau mempertimbangkan membeli dari website tersebut di masa depan dimana konsumen tidak akan berpindah ke website lain. Menurut Hur et al., 2011 dalam (Prasetya \& Idris, 2014) mendefinisikan e-loyalty sebagai niatan pelanggan untuk mengunjungi website kembali dengan atau tanpa terjadinya transaksi online. Definisi ini menganggap loyalitas pelanggan sebagai sikap membangun dan berpotensi. Loyalitas pelanggan tercipta karena pelanggan merasa puas sehingga akan mendorong pelanggan untuk membeli dan mengkonsumsi ulang produk tersebut.

Disampaikan oleh Schnaars dalam (Komara, 2013) terciptanya kepuasan pelanggan dapat memberikan beberapa manfaat, di antaranya hubungan antara perusahaan dan pelanggannya menjadi harmonis, memberikan dasar yang baik bagi pembelian ulang, terciptanya loyalitas pelanggan terhadap suatu produk tertentu dan membentuk suatu rekomendasi dari mulut ke mulut yang menguntungkan bagi perusahaan. E-loyalty meliputi keinginan akan kecenderung konsumen terhadap e-retailing dan hasilnya dalam suatu perilaku pembelian ulang. Rachjaibun (2007) dalam (Christian \& Nuari, 2014) mengatakan bahwa pelanggan loyal merupakan salah satu penggerak penting untuk kesuksessan marketplace maupun e-commerce.

\section{METODE PENELITIAN \\ Sifat Penelitian}

Penelitian ini bersifat kuantitatif. Penelitian kuantitatif adalah penelitian ilmiaah yang sistematis terhadap bagian-bagian dan fenomena serta hubungan-hubungannya. Tujuannya adalah mengembangkan dan menggunakan model-model yang sistematis, teori-teori, dan hipotesis yang berkaitan dengan fenomena alam. Penelitian ini dimaksudkan. Penelitian ini dimaksudkan menggambarkan suatu keadaan obyek tertentu yang memiliki atau dioengaruhi oleh faktor lain dan menarik kesimpulannya berdasarkan angka yang diolah dengan sara statistik.

Penelitian ini dilakukan guna mengetahui hubungan antar variabel yang terdiri dari variabel Hedonic Shopping Value, variabel Web Informativeness, variabel Web Entertainment, variabel E-satisfaction, dan variabel E-Loyalty dengan melakukan survei terhadap pelanggan Tokopedia. 


\section{Teknik analisis data}

Tenik pengambilan sampelnya menurut (Sugiyono, 2010) teknik sampling pada dasarnya dapat dikelompokkan menjadi dua yaitu probability sampling dan nonprobability sampling. Dalam penelitian ini menggunakan teknik Nonprobability Sampling. Lebih spesifik lagi teknik yang digunakan dalam penelitian ini adalah Accidentan Sampling yaitu pengambilan sampel yang dilakukan berdasarkan pertimbangan yang sesuai dengan maksud peneliti, dan berdasarkan spontanitas. Dalam penelitian ini, kriteria responden yaitu pelanggan pengguna Tokopedia yang berumur diatas 15 tahun.

\section{Analisis Deskriptif}

Statistik deskriptif adalah statistik yang berfungsi untuk mendeskripsikan obyek yang diteliti melalui data sampel atau populasi sebagaimana adanya, tanpa melakukan analisis yang kemudian diberi kesimpulan yang general. (Ghozali,2011).

\section{Karakteristik Responden}

Data karakteristik responden dalam penelitian berdasarkan jenis kelamin dari 100 responden menunjukan persentase pengguna Tokopedia yaitu 45 persen pengguna laki-laki dan 55 persen pengguna perempuan. Dengan umur 16 tahun sd. 19 tahun 21 persen. Umur 20 sd. 23 tahun 57 persen. Umur 24 sd.30 tahun 18 persen. Umur 31 sd 40 tahun 4 persen. Karakteristik berdasarkan provinsi responden Aceh 1 persen, Riau 3 persen, Sumatra Barat 2 persen, Bangka Belitung 2 persen, Sumatra Selatan 2 persen, Lampung 1 persen, Banten 1 persen, Jakarta Barat 2 persen, Jakarta Utara 3 persen, Jakarta Timur 2 persen, DKI Jakarta 2 persen, Jawa Barat 9 persen, Jawa tengah 10 persen, DI Yogyakarta (48\%), Jawa Timur 5 persen, Bali 2 persen, Kalimantan Barat 5 persen.

\section{HASIL DAN PEMBAHASAN \\ Uji Validitas}

Dari hasil pengolahan validitas data, maka dapat dinyatakan bahwa dari total butir pertanyaan pada semua variabel dinyatakan Valid, karena $r$ hitung $>r$ tabel yaitu 0,196. Variabel Hedonic Shopping Value sebesar 0,662 sd. 0,849. Variabel web informativeness 0,770 sd. 0,874. Web Entertainment sebesar 0,789 sd. 0,857. Variabel e-satisfaction sebesar 0,857 sd. 0,900. Dan variabel e-loyalty sebesar 0,64 sd. 0,922. Maka dapat disumpulkan setiab butir pertanyaan dari setiap variabel dinyatakan valid.

\section{Uji Reabilitas}

Berikut merupakan hasil uji reabilitas dari masing-masing variabel yang digunakan dalam penelitian. Data dikatakan reliable apabila r-alpha $>$ r-tabel. Pengujian reabilitas dengan mengunakan tingkat signifikansi 0,05 koefisien alpha, serta nilai r-tabel dengan nilai $\mathrm{n}=98$ sebesar 0.1966. Hasil uji reabilitas variabel Hedonic Shopping Value menunjukan Cronbach's Alpha 0,773. Web Infirmativeness yang menunjukan 0,867. Variabel Web Entertainment 0,881 . E-Satisfaction 0,881. e-loyalty 0,946. Yang artinya semua variabel lebih besar dari r-alpha, sehingga dinyatakan reliable. 


\section{Uji Asumsi Klasik Normalitas}

Uji ini untuk menguji apakah pengalaman berdistribusi secara normal atau tidak, uji ini menggunakan kolmogrov smirnov. Data dikatakan terdistribusi normal apabila tingkat signifikasi $>0,05$. Sehingga dapat disimpulkan bahwa variabel tersebut terdistribusi secara normal. (Ghozali et al., 2019). Hasil pengujian yang telah dilakukan bahwa nilai Asymp. Sig adalah 0,469 dengan artian nilai signifikasi > 0,05.

Tabel 1. Multikolinieritas

\begin{tabular}{l|cc}
\hline \multirow{2}{*}{ Model } & \multicolumn{2}{c}{ Colinier Statistics } \\
\cline { 2 - 3 } & Tolerance & VIF \\
\hline \multirow{2}{*}{ Hedonic Shopping Value } & 0,659 & 1,517 \\
Web Informativeness & 0,470 & 2,126 \\
Web Entertainment & 0,520 & 1,922 \\
e-satisfaction & 1,000 & 1,000 \\
\hline
\end{tabular}

Tidak terjadi multikolinieritas apabila nilai VIF $<10$, dan tolerance value $>0,1$. Diketahui bahwa nilai VIF dari variabel Hedonic Shopping Value (X1) adalah 1,517. Variabel Web Informativeness (X2) adalah 2,126. Dan variabel Web Entertainment (X3) sebesar 1,922. Disimpulkan nilai VIF dari variabel X1 X2 X3 $<10$. Sedangkan nilai tolerance dari variabel X1, X2, X3 masing-masing 0,659 0,470 dan 0,520 yang berarti $>0,1$. Maka data tersebut tidak terjadi multikolinieritas. Dari tabel 4.18, dapat diketahui bahwa nilai VIF dari variabel Satisfaction (Y1) adalah 1,000 sehingga nilai VIF variabel Y1 $<10$. Sedangkan nilai tolerance dari Y1 adalah 1,000 yang berarti > 0,1. Maka data tersebut tidak terjadi multikolinieritas.

\section{Heterokedastisitas}

Diketahui t tabel adalah 1,984. Nilai t hitung dari LnX1, LnX2, dan LnX3 masingmasing $-0,56 \quad 0,742$ dan $-0,752$. Nilai $\mathrm{t}$ hitung berada diantara $-\mathrm{t}$ tabel $\leq \mathrm{t}$ hitung $\leq \mathrm{t}$ tabel, maka $\mathrm{H}_{0}$ diterima. Artinya pengujian antara LnX1 LnX2 LnX3 dengan $\mathrm{Lnei}^{2}$ tidak ditemukan adanya gejala heterokedastisitas. Serta pengujian LnY1 t hitungnya adalah 0,551 maka pengujian antara LnY1 dengan $\mathrm{Lnei}^{2}$ tidak terdapat gejala heterokedastisitas. 
Tabel 2. Uji Hipotesis

\begin{tabular}{lcccc}
\hline \multicolumn{1}{c}{ Variabel } & B & t hitung & Sig t & Keterangan \\
\hline \multicolumn{1}{c}{ Constant) } & 3,940 & 3,516 & 0,001 & \\
Hedonic & 0.030 & 0,415 & 0.679 & Tidak Signifikan \\
Winformative & 0.333 & 3,568 & 0,001 & Signifikan \\
Wentertaiment & 0,108 & 1,533 & 0,129 & Tidak Signifikan \\
R square & 0.347 & & & \\
\hline
\end{tabular}

1) Tingkat signifikan variabel hedonic shopping value sebesar 0,679 atau > dari 0,05 sehingga tidak bisa dikatakan signifikan. Koefisien regresi Hedonic shopping value sebesar 0,030 dan bernilai positif menyatakan bahwa setiap peningkatan Hedonic shopping value sebesar 1 akan menyebabkan meningkatnya nilai E-Satisfaction sebesar 0,030. Maka hipotesis 1 diterima.

2) Tingkat signifikan variabel web informativeness seberas $0,001<0,05$ sehingga dikatakan signifikan. Koefisien regresi Web Informativeness sebesar 0,333 dan bernilai positif menyatakan bahwa setiap peningkatan Web Informativeness sebesar 1 akan menyebabkan meningkatnya nilai E-Satisfaction sebesar 0,333. Maka hipotesis 2 diterima.

3) Tingkat signifikan web entertainment sebesar 0,129 yang artinya > dari 0,05 sehingga dikatakan tidak signifikan. Koefisien regresi Web Entertainment sebesar 0,108 dan bernilai positif menyatakan bahwa setiap peningkatan Web Informativeness sebesar 1 akan menyebabkan meningkatnya nilai E-Satisfaction sebesar 0,108. Maka hipotesis 3 diterima.

Tabel 3. Pengujian Variabel Independent Terhadap Dependent

Coefficients $^{\mathrm{a}}$

\begin{tabular}{lccccc}
\hline Model & \multicolumn{2}{c}{$\begin{array}{c}\text { Unstandardized } \\
\text { Coefficients }\end{array}$} & $\begin{array}{c}\text { Standardized } \\
\text { Coefficients }\end{array}$ & & \\
\cline { 2 - 4 } & B & Std. Error & Beta & T & Sig. \\
\hline (Constant) & 7,063 & 2,537 & & 2,784 &, 006 \\
Satisfaction (Y1) & 1,178 &, 216 &, 483 & 5,463 &, 000 \\
\hline
\end{tabular}

a. Dependent Variable: Loyalty (Y2)

Hasil pengujian variabel independent terhadap dependent terlihat bahwa e-satisfaction berpengaruh secara positif dan signifikan terhadap e-loyalty, hal ini ditunjukan dengan nilai signifikan 0,000 lebih kecil dari $\alpha=5 \%$ atau 0,05 . Koefisien regresi e-Satisfaction sebesar 1,178 dan bernilai positif menyatakan bahwa setiap peningkatan e-satisfaction sebesar 1 akan menyebabkan meningkatnya nilai E-loyalty sebesar 1,178. Sehingga hipotesis 4 diterima. 
Uji F

Tabel 4. Uji F Dependen E-Satisfaction

\begin{tabular}{lccccc}
\multicolumn{6}{c}{ ANOVA $^{\mathbf{a}}$} \\
\multicolumn{1}{c}{ Model } & Sum of Squares & Df & Mean & \multirow{2}{*}{ F } & \multirow{2}{*}{ Sig. } \\
\hline Regression & 124,711 & 3 & 41,570 & 16,976 &, 000 \\
1 Residual & 235,079 & 96 & 2,449 & & \\
Total & 359,790 & 99 & & & \\
\hline
\end{tabular}

a) Dependent Variable: Satisfaction(Y1)

b) Predictors: (Constant), WEntertaint(X3), Hedonic(X1), Winformative(X2)

Pada tabel menunjukan nilai signifikansi adalah 0,000 yang berarti kurang dari nilai $\alpha 0,05$ dan nilai $\mathrm{F}$ hitung menunjukan nilai 16,976 angka tersebut lebih besar dari nilai $\mathrm{F}$ tabel sebesar 2,70 .

Sehingga dapat dinyatakan bahwa ketiga variabel (X), yaiyu hedonic shopping value, web informativeness, dan web entertainmnet pada uji $\mathrm{f}$ yang dilakukan mempunyai pengaruh secara simultan terhadap variabel E-satisfaction (Y).

Tabel 5. Uji F Dependen E-Loyalty

\begin{tabular}{llcccc}
\multicolumn{7}{c}{ ANOVA $^{\text {a }}$} \\
\hline \multirow{2}{*}{ Model } & Sum of Squares & Df & $\begin{array}{c}\text { Mean } \\
\text { Square }\end{array}$ & F & \multirow{2}{*}{ Sig. } \\
\hline \multirow{2}{*}{$\begin{array}{l}\text { Regression } \\
\text { Residual }\end{array}$} & 499,339 & 1 & 499,339 & 29,840 &, $000^{6}$ \\
Total & 1639,901 & 98 & 16,734 & & \\
\hline
\end{tabular}

a) Dependent Variable: Loyalty(Y2)

b) Predictors: (Constant), Satisfaction(Y1)

Pada tabel tersebut menunjukan nilai signifikansi adalah 0,000 atau kurang dari nilai $\alpha$ 0,05 dan nilai $\mathrm{F}$ hitung menunjukan 29,840 angka tersebut lebih besar dari nilai $\mathrm{F}$ tabel sebesar 2,70. sehingga dinyatakan bahwa variabel e-satisfaction pada uji $F$ yang dilakukan mempunyai pengaruh secara simultan terhadap variabel e-loyalty. 


\section{Koefisien Determinasi}

Tabel 6. Uji Koefisien Determinasi Dependen E-Satisfaction

\begin{tabular}{ccccc}
\multicolumn{6}{c}{ Model Summary } \\
\hline Model & $\mathrm{R}$ & R Square & $\begin{array}{c}\text { Adjusted R } \\
\text { Square }\end{array}$ & $\begin{array}{c}\text { Std. Error of the } \\
\text { Estimate }\end{array}$ \\
\hline 1 &, $589^{\mathrm{a}}$ &, 347 &, 326 & 1,56485 \\
\hline
\end{tabular}

a. Predictors: (Constant), WEntertaint(X3), Hedonic(X1),Winformative(X2)

Sumber data premier : diolah pada tahun 2021

Besar pengaruh hedonic shopping value, web informativeness, dan web entertainment secara simultan terhadap e-satisfaction ditunjukan dengan nilai $\mathrm{R}$ Squere sebesar 0,347. Artinya 34,7\% dipengaruhi oleh hedonic shopping value, web informativeness, dan web entertainmnet. Dan 65,3\% dipengaruhi variabel yang lain.

Tabel 7. Uji Koefisien Determinasi Dependen E-Loyalty

Model Summary

\begin{tabular}{ccccc}
\hline Model & $\mathrm{R}$ & R Square & $\begin{array}{c}\text { Adjusted R } \\
\text { Square }\end{array}$ & $\begin{array}{c}\text { Std. Error of the } \\
\text { Estimate }\end{array}$ \\
\hline 1 &, $483^{\mathrm{a}}$ &, 233 &, 226 & 4,09068 \\
\hline
\end{tabular}

a. Predictors: (Constant), Satisfaction(Y1)

Dari tabel tersebut besar pengaruh e-satisfaction terhadap e-loyalty ditunjukan dengan nilai $\mathrm{R}$ squere sebesar 0,233 . Artinya $23,3 \%$ dipengaruhi oleh e-satisfaction dan $76,7 \%$ dipengaruhi variabel yang lain.

\section{Pengaruh Hedonic Shopping Value Terhadap E-Satisfaction.}

Berdasarkan pengujian hipotesis yang telah dilakukan, dapat dinyatakan bahwa Hedonic Shopping Value berpengaruh positif terhadap variabel E-Satisfaction. Hal ini dapat dibuktikan dengan analisis linier berganda yang telah dilakukan menunjukan bahwa nilai $\mathrm{t}$ hitung 0,415 dnegan nilai sign adalah 0,679>0,05. Yang artinya $\mathrm{H}_{1}$ diterima.

\section{Pengaruh Web Informativeness Terhadap E-Satisfaction.}

Dengan hasil pengujian hipotesis yang telah dilakukan, berdasarkan hasil regresi dinyatakan bahwa variabel Web Informativeness berpengaruh postif terhadap E-Satisfaction, didukung dengan hasil pengujian yang disajikan pada tabel regresi dengan nilai t hitung 3,568. Dengan nilai sign menunjukan 0,001 artinya lebih kecil dari 0,05. Sehingga dinyatakan bahwa $\mathrm{H}_{2}$ diterima. 


\section{Pengaruh Web Entertainment Terhadap E-Satisfaction}

Hasil pengujian menunjukan variabel Web Entertainment berpengaruh positif terhadap ESatisfaction. Hal ini ditunjukan pada tabel 4.21 dengan nilai t hitung 1,533 dengan nilai sign sebesar 0,129>0,05. Sehingga $\mathrm{H}_{3}$ diterima.

\section{Pengaruh E-Satisfaction terhadap E-Loyalty}

Hasil pengujian hipotesis ini menyetakan bahwa variabel E-Satisfaction berpengaruh positif terhadap E-Loyalty. Artinya apabila semakin meningkat E-satisfaction maka semakin meningkat pula E-Loyalty. Hal tersebut dibuktikan dengan nilai t hitung sebesar 5,463 dengan nilai signifikan 0,000 lebih kecil dari $\alpha=5 \%$ atau 0,05 . Sehingga $\mathrm{H}_{4}$ diterima.

Dalam hal ini artinya responden setuju dengan kepuasan yang mereka rasakan menjadikan faktor yang signifikan terhadap meningkatnya loyalitas pengguna tokopedia dalam penelitian ini.

\section{KESIMPULAN}

Berdasarkan hasil dan pembahasan, penelitian bertujuan menguji hedonic shopping value, web informativeness, dan web entertainmnet terhadap e-loyalty dengan melalui esatisfaction sebagai intervening pada pengguna tokopedia. Temuan penelitian menunjukan adanya pengaruh positif hedonic shopping value, web informativeness, web entertainmnet terhadap e-satisfaction dan pengaruh positif e-satisfaction terhadap e-loyalty pada pengguna tokopedia. sehingga pihak tokopedia perlu dalam mempertahankan informasi serta entertainment yang terdapat pada tokopedia dalam meningkatkan kepuasan penggunanya sehingga dapat diharapkan timbulnya loyalitas penggguna

\section{DAFTAR PUSTAKA}

Arnold, M. J., \& Reynolds, K. E. (2012). Approach and avodance motivation : investiggating hedonic consumtion in a retail setting. Journal of Retailing, 88, 399-411.

Christian, M., \& Nuari, V. (2014). Konsumen Studi Kasus : Belanja Online Bhinneka . Com. Jurnal Siasat Bisnis Vol. 20 No. 1, Januari 2016.

Ciputrauceo.net. (2015). Perilaku Konsumen: Definisi dan Proses Mengenali Perilaku Konsumen. Retrieved from http://ciputrauceo.net/blog/2015/6/11/perilaku-konsumen

Databoks. (2019). Indonesia Jadi Negara dengan Pertumbuhan E-Commerce Tercepat di Dunia. Retrieved from https://databoks.katadata.co.id

Dehghani, M., Khorram, M., Ramezani, I., \& Sali, R. (2016). Computers in Human Behavior Evaluating the in $\mathrm{fl}$ uence of YouTube advertising for attraction of young customers. Computers in Human Behavior, 59,165-172. https://doi.org/10.1016/j.chb.2016.01.037

Gangadharbatla, Harsha, \& Daugherty, T. (2013). Advertising versus product placements : How consumers assess the value of each. Journal of Current Issues \& Research in Advertising, 34(1), 21-38.

Ghozali, F. A., Studi, P., Matematika, P., Keguruan, F., Ilmu, D. A. N., \& Surakarta, U. M. (2019). Pembelajaran matematika dengan model discovery learning ( dl ) dan problem based learning ( $\mathrm{pbl}$ ) ditinjau dari kemandirian siswa, (Dl).

iPrice.co.id. (2020). Daftar 50 Website \& Aplikasi (Map of Ecommerce). Retrieved from https://iprice.co.id/insights/mapofecommerce

Komara, A. T. (2013). Pengaruh E-Service Quality Dan E-Recovery Service Quality Terhadap E-Satisifaction Serta Implikasinya Pada E-Loyalty Pelanggan Maskapai Penerbangan. Jurnal Ekonomi, Bisnis \& Entrepreneurship, 7(2), 105-115. 
Kotler, P., \& Armstrong, G. (2012). Principles of marketing: an Asian perspective.

Maulana, S. M., Susilo, H., \& Riyadi. (2015). Implementasi E-Commerce Sebagai Media Penjualan Online (Studi Kasus Pada Toko Pastbrik Kota Malang). Jurnal Administrasi Bisnis, 29.

Prasetya, \& Idris. (2014). Filo Novandi Prasetya ; Idris Gautama So. BINUS BUSINESS REVIEW, 5(9), 8-17.

Sugiyono. (2010). Metode Penelitian Pendidikan Pendekatan Kuantitatif, Kualitatif, dan R\&D. Bandung: Alfabeta.

Sugiyono. (2011). Metode Penelitian Pendidikan Pendekatan Kuantitatif, Kualitatif, dan R\&D. Bandung: Alfabeta.

Tokopedia. (2020). Cerita Tokopedia. Retrieved from https://www.tokopedia.com/about/ourstory

Udayana, I B N, \& Pramana, A. (2019). Membangun Kepercayaan Konsumen untuk Meningkatkan Intensi Pembelian, 7, 112-123. Retrieved from http://jurnal.unmer.ac.id/index.php/jmdk

Valvi, A. C., \& Konstantinos, F. C. (2012). Critical review of the e-loyalty literature: a purcase-centred framework, 12(3), 331-378.

Vijay, T. S., Prashar, S., \& Sahay, V. (2019). The Influence of Online Shopping and web Atmospheric Cues on E-Loyalty: Mediating Role of E-Satisfaction. Journal of Theoreticl and Applied Electronic Commerce Research, 14(1). https://doi.org/10.4067/S0718-18762019000100102 
